\title{
Changes in aggregate-associated organic carbon and nitrogen after 27 years of fertilization in a dryland alfalfa grassland on the Loess Plateau of China
}

\author{
ZHANG Liqiong ${ }^{1,2}$, WEI Xiaorong ${ }^{1,3}$, HAO Mingde ${ }^{1,3 *}$, ZHANG Meng ${ }^{1,3}$ \\ ${ }^{1}$ College of Natural Resources and Environment, Northwest A\&F University, Yangling 712100, China; \\ ${ }^{2}$ College of Agriculture and Life Sciences, Ankang University, Ankang 725000, China; \\ ${ }^{3}$ State Key Laboratory of Soil Erosion and Dryland Farming in the Loess Plateau, Northwest A\&F University, Yangling 712100, China
}

\begin{abstract}
Changes in the distribution of soil aggregate sizes and concentrations of aggregate-associated organic carbon $(\mathrm{OC})$ and nitrogen $(\mathrm{N})$ in response to the fertilization of grasslands are not well understood. Understanding these changes is essential to the sustainable development of artificial grasslands. For understanding these changes, we collected soil samples at $0-20$ and $20-40 \mathrm{~cm}$ depths from a semi-arid artificial alfalfa grassland after 27 years of applications of phosphorus (P) and nitrogen+phosphorus+manure (NPM) fertilizers on the Loess Plateau of China. The distribution of aggregate sizes and the concentrations and stocks of $\mathrm{OC}$ and $\mathrm{N}$ in total soils were determined. The results showed that NPM treatment significantly increased the proportions of $>2.0 \mathrm{~mm}$ and 2.0-0.25 mm size fractions, the mean geometric diameter (MGD) and the mean weight diameter (MWD) in the 0-20 $\mathrm{cm}$ layer. Phosphorous fertilizer significantly increased the proportion of $>2.0 \mathrm{~mm}$ size fractions, the MGD and the MWD in the $0-20 \mathrm{~cm}$ layer. Long-term application of fertilization ( $P$ and NPM) resulted in the accumulation of OC and $N$ in soil aggregates. The largest changes in aggregate-associated $O C$ and $N$ in the $0-20 \mathrm{~cm}$ layer were found at the NPM treatment, whereas the largest changes in the $20-40 \mathrm{~cm}$ layer were found at the P treatment. The results suggest that long-term fertilization in the grassland leads to the accumulation of $\mathrm{OC}$ and $\mathrm{N}$ in the coarse size fractions and the redistribution of $\mathrm{OC}$ and $\mathrm{N}$ from fine size fractions to coarse size fractions.
\end{abstract}

Keywords: alfalfa grassland; long-term fertilization; nitrogen; organic carbon; semi-arid Loess Plateau

Citation: ZHANG Liqiong, WEI Xiaorong, HAO Mingde, ZHANG Meng. 2015. Changes in aggregate-associated organic carbon and nitrogen after 27 years of fertilization in a dryland alfalfa grassland on the Loess Plateau of China. Journal of Arid Land, 7(4): 429-437. doi: $10.1007 /$ s40333-015-0003-6

Alfalfa plants can improve soil quality by increasing aboveground and belowground biomass while providing canopy coverage, thus decreasing erosion and soil nutrient loss caused by water and wind (Blanco and Lal, 2004). Due to its high N content, alfalfa is high-quality forage for livestock and has been extensively used for stockbreeding around the world (Badaruddin and Meyer, 1989). Alfalfa is widely planted on the Loess Plateau, where soil erosion is a serious problem. The management of artificial alfalfa grassland is thus important for the prevention of soil erosion and for the development of local agriculture. The most widely used management practice for alfalfa grassland is the application of phosphorus $(\mathrm{P})$ and manure fertilizers, which can significantly increase plant biomass (Fan et al., 2011). Although an understanding of the effects of fertilization on soil structure and on the amounts of organic carbon (OC) and nitrogen (N) in loess is essential for the sustainable development of the artificial grasslands, these effects have not yet been studied.

The distribution of soil aggregates can provide important information on changes in the structure and physical properties of soil (Cammeraat and Imeson,

*Corresponding author: HAO Mingde (E-mail: mdhao@ms.iswc.ac.cn)

Received 2014-07-11; revised 2015-01-05; accepted 2015-01-14

(C) Xinjiang Institute of Ecology and Geography, Chinese Academy of Sciences, Science Press and Springer-Verlag Berlin Heidelberg 2015 
1998). Soil organic matter, OC and $\mathrm{N}$ can indicate soil fertility (Gregorich et al.. 1997; Lal et al., 1997). Soil structure and organic matter are interrelated; organic matter acts as a binding agent to facilitate aggregation, and aggregation mediates many biological and physical processes that in turn affect the accumulation of organic matter in soils (Elliott, 1986; Beare et al., 1994; Six et al., 2000).

Many experiments conducted in croplands have indicated that soil organic matter and the stability of aggregates are sensitive to tillage and the management of fertilization (Beare et al., 1994; Pinheiro et al., 2004; Madari et al., 2005). The continuous application of fertilizers can increase soil OC and N contents, aggregate stability and soil biological activities, all of which are associated with soil aggregation (Reeder et al., 1998; Schunman et al., 2002). In addition, OC and $\mathrm{N}$ contents of soil aggregates and the stability of soil aggregates are significantly enhanced after the long-term application of manure (Whalen and Chang, 2002; Whalen et al., 2003). These increases in soil OC and $\mathrm{N}$ mainly occurred in macro-aggregates (Aoyama et al., 1999). Previous studies have suggested that fertilization may influence the interaction between soil organic matter and aggregation and thus prevent the loss of soil OC and N (Blanco and Lal, 2004). Most of these studies, however, have been conducted on croplands. Grassland ecosystem is sensitive to climatic change, and it has significant impact to the global carbon cycle. Nevertheless, studies of soil OC in soil aggregates of grassland is relatively few (He et al., 2008; Shrestha and Stahi, 2008), and little is known about the responses of soil aggregate sizes distributions or $\mathrm{OC}$ and $\mathrm{N}$ concentrations within aggregates to grassland fertilization, particularly artificial alfalfa grassland fertilization, which differs greatly from cropland fertilization.

In this study, we investigated the distribution of soil aggregate sizes, as well as the concentrations of OC and $\mathrm{N}$ in total soils and separated aggregates in a semi-arid, artificial alfalfa grassland on the Loess Plateau of China after applying $\mathrm{P}$ and nitrogen+phosphorus + manure (NPM) fertilizers annually for 27 years. The objective of this study was to understand the responses of soil structure and the accumulation of $\mathrm{OC}$ and $\mathrm{N}$ in aggregates to long-term fertilization in artificial alfalfa grasslands. This knowledge may provide a useful guide for the management of alfalfa and other legumes in grasslands on the Loess Plateau, or similar regions.

\section{Materials and methods}

\subsection{Study area}

A long-term field experiment was initiated in September 1984 at the Agro-ecological Experimental Station of the Chinese Academy of Sciences, Changwu county, Shaanxi province, China $\left(35^{\circ} 12^{\prime} \mathrm{N}, 107^{\circ} 40^{\prime} \mathrm{E}\right)$. The experiment was arranged on dry farmland that did not require irrigation. The study site has a warmtemperate, semi-arid and continental climate. During the period 1984 to 2011, the annual average temperature was $9.1{ }^{\circ} \mathrm{C}$, and the average frost-free period was 171 days. The annual accumulation of temperatures higher than $0^{\circ} \mathrm{C}$ and $10^{\circ} \mathrm{C}$ were $3,866^{\circ} \mathrm{C}$ and $3,029^{\circ} \mathrm{C}$, respectively. The average annual precipitation was $584 \mathrm{~mm}$. Rainfall occurs mainly between June and September, with a large variation in intensity within and between years. The soil is known as Heilu soil, which corresponds to Calcarid Regosol, according to the FAO/UNESCO classification system (FAO, 1998). The soil properties are shown in Table 1. Soil loss due to water and wind erosion is very low.

Table 1 Main chemical properties of the top soil layer $(0-20 \mathrm{~cm})$ at the start of the experiment in 1984 (Wei et al., 2006)

\begin{tabular}{lc}
\hline Soil chemical property & Content \\
\hline Organic matter $(\mathrm{g} / \mathrm{kg})$ & 10.5 \\
Total nitrogen $(\mathrm{g} / \mathrm{kg})$ & 0.80 \\
Available nitrogen $(\mathrm{mg} / \mathrm{kg})$ & 37.0 \\
Total phosphorous $(\mathrm{g} / \mathrm{kg})$ & 0.7 \\
Available phosphorous $(\mathrm{mg} / \mathrm{kg})$ & 3.0 \\
Available potassium $(\mathrm{mg} / \mathrm{kg})$ & 129.3 \\
$\mathrm{CaCO}_{3}(\mathrm{~g} / \mathrm{kg})$ & 108.4 \\
\hline
\end{tabular}

\subsection{Experimental design and soil sampling}

A long-term fertilization experiment on artificial alfalfa grassland was conducted in plots of $10.3 \mathrm{~m} \times 6.5$ $\mathrm{m}$. The experiment included a control (CK), a $\mathrm{P}$ and a NPM treatment. Plots were randomly arranged with three replicates each. The alfalfa plant was sown in 1984. In mid-April of each year, fertilizers were broadcasted on the surface of soil. The land was then 
tilled with a moldboard plough to a depth of approximately $10 \mathrm{~cm}$ to mix the fertilizers with the soil. The CK treatment was also tilled so as to minimize the effects of tillage on the experimental results. The alfalfa plant was cut and removed in mid-June and mid-October each year. Previous studies demonstrated that no significant changes in soil $\mathrm{OC}$ and $\mathrm{N}$ occurred in the CK treatment between 1984 and 2011 (Wei et al., 2006; Fan et al., 2011). This suggests that tillage has negligible effects on the three treatments, and any changes in the distribution of aggregate size fractions $\mathrm{OC}$ and $\mathrm{N}$ levels in total soils and associated with aggregates were due to the fertilization.

Urea and superphosphate were used as the source of $\mathrm{N}$ and $\mathrm{P}$. The manure came from cattle. In the $\mathrm{P}$ treatment, the $\mathrm{P}$ addition was $26 \mathrm{~kg} /\left(\mathrm{hm}^{2} \cdot \mathrm{a}\right)$. In the $\mathrm{NPM}$ treatment, the $\mathrm{N}$ addition was $120 \mathrm{~kg} /\left(\mathrm{hm}^{2} \cdot \mathrm{a}\right)$, the $P$ addition was $26 \mathrm{~kg} /\left(\mathrm{hm}^{2} \cdot \mathrm{a}\right)$ and the manure addition was $75 \mathrm{t} /\left(\mathrm{hm}^{2} \cdot \mathrm{a}\right)$, respectively. Manure OC and N contents were 17.67 and $1.97 \mathrm{~g} / \mathrm{kg}$, respectively, and available $\mathrm{N}$ was $91 \mathrm{mg} / \mathrm{kg}$. Total $\mathrm{P}$ content of the manure was $0.97 \mathrm{~g} / \mathrm{kg}$ and available $\mathrm{P}$ was $115 \mathrm{mg} / \mathrm{kg}$.

Soil bulk density was measured at depths of $0-20$ and $20-40 \mathrm{~cm}$ for each plot using a stainless steel cutting ring $5.0-\mathrm{cm}$ long and $5.0-\mathrm{cm}$ in diameter. The soil cores were dried at $105^{\circ} \mathrm{C}$ for $24 \mathrm{~h}$ to a constant weight. Soil samples were collected in September 2011. Five random cores were taken at $0-20$ and 20-40 cm depths for each plot using a tube auger $5-\mathrm{cm}$ in diameter. The five cores samples from each soil layer were mixed. Visible pieces of organic material were removed by hand. Soil samples were brought to the laboratory, air dried and prepared for the analysis of soil aggregates, OC concentrations and $\mathrm{N}$ concentrations.

\subsection{Laboratory analysis}

Four size fractions of aggregates were separated by wet sieving each sample through 2, 0.25 and 0.053 $\mathrm{mm}$ sieves following the procedures described by Cambardella and Elliott (1994). The aggregate size samples were dried in an oven at $50^{\circ} \mathrm{C}-60^{\circ} \mathrm{C}$, weighed and stored at room temperature.

The mean weight diameter (MWD) and mean geometric diameter (MGD) were used to evaluate soil structure and were calculated as follows (Bavel, 1950; Pinheino et al., 2004):

$$
\begin{gathered}
M W D=\sum X_{i} W_{i} \\
M G D=\exp \left(\sum\left(W_{i} \times \log X_{i} / 100\right)\right) .
\end{gathered}
$$

Where $X_{i}$ and $W_{i}$ are the mean diameter $(\mathrm{mm})$ and proportion (\%) of each size fraction of the aggregate, respectively.

A subsample of air-dried, undisturbed soil from each plot was ground to pass through a $0.25-\mathrm{mm}$ sieve to measure $\mathrm{OC}$ and $\mathrm{N}$ in total soils. $\mathrm{OC}$ and $\mathrm{N}$ for total soils and different aggregate size fractions were analyzed using a $\mathrm{C} / \mathrm{N} / \mathrm{H} / \mathrm{S}$-analyzer (Vario ElementarIII, Germany).

Stocks of soil OC (or N) $(\mathrm{Mg} \mathrm{C}($ or N)/hm²) in total soils were calculated as follows:

Stocks of $\mathrm{OC}($ or $\mathrm{N})=\mathrm{D} \times \mathrm{BD} \times \mathrm{OC}($ or $\mathrm{N}) / 10$.

Where $\mathrm{D}$ is the thickness of the soil layer $(\mathrm{cm}), \mathrm{BD}$ is the bulk density $\left(\mathrm{g} / \mathrm{cm}^{3}\right)$, and $\mathrm{OC}$ (or N) is the concentration of $\mathrm{OC}($ or $\mathrm{N})$ in the soil layer $(\mathrm{g} / \mathrm{kg})$.

Stocks of OC (or N) $(\mathrm{Mg} \mathrm{C}($ or N)/hm²) in each size fraction were calculated as follows:

Stocks of $O C_{i}\left(\right.$ or $\left.N_{i}\right)=D \times B D \times M_{i} \times O C_{i}\left(\right.$ or $\left.N_{i}\right) / 10000$.

Where $M_{i}$ is the aggregate mass in the $i^{\text {th }}$ size fraction $(\mathrm{g} / \mathrm{kg})$, and $O C_{i}\left(\right.$ or $\left.N_{i}\right)$ is the $\mathrm{OC}$ (or $\left.\mathrm{N}\right)$ concentration of the $i^{\text {th }}$ size fraction ( $\mathrm{g} / \mathrm{kg}$ aggregate) for the selected soil layer.

\subsection{Statistical analysis}

A two-way analysis of variance was conducted using SAS version 8 to test the effects of fertilization and soil depth on soil aggregate size distribution, MWD, MGD and OC and N concentrations and stocks in total soils and aggregates. The values of each variable were compared at the $P<0.05$ level of significance using the least significant difference for the variance.

\section{Results}

\subsection{The effects of long-term fertilization on the distribution of soil aggregate sizes}

The $<0.053$-mm fraction comprised the largest proportion of soil aggregates and accounted for $40 \%$ of the total soil mass in both layers, whereas the $>2.0-\mathrm{mm}$ fraction accounted for the smallest percentage of soil mass at both soil depths $(13 \%$ and $7 \%$, respectively) (Fig. 1). NPM treatment of 27 years significantly increased the proportions of $>2.0-\mathrm{mm}$ and $2.0-0.25-\mathrm{mm}$ fraction and decreased the proportion of 
$<0.053$-mm fraction in the $0-20 \mathrm{~cm}$ layer. Phosphorous fertilizer, however, increased the proportion of $>2.0-\mathrm{mm}$ fraction and decreased the proportion of $<0.053-\mathrm{mm}$ fraction in the $0-20 \mathrm{~cm}$ layer, but did not significantly change the distribution of soil aggregates in the 20-40 cm layer. Similarly, the NPM treatment increased the proportion of MGD and MWD by $58 \%$ and $98 \%$, respectively, in the $0-20 \mathrm{~cm}$ layer $(P<0.05)$, whereas the $\mathrm{P}$ treatment increased the proportion of MGD and MWD by $21 \%$ and $22 \%$, respectively, in the 20-40 cm layer $(P>0.05)$ (Fig. 2). These results suggest that the effects of long-term fertilization on the distribution of soil aggregate fractions varied with fertilizer types and soil depths.

\subsection{The effects of long-term fertilization on OC and $\mathbf{N}$ in total soils}

Long-term fertilization increased $\mathrm{OC}$ in non-sieved soils in the $0-20 \mathrm{~cm}$ layer (Fig. 3). The P treatment increased $\mathrm{OC}$ concentrations and stocks by $16 \%$ and $15 \%(P>0.05)$, respectively, whereas the NPM treatment increased them by $50 \%$ and $35 \%(P<0.05)$, respectively. Soil $\mathrm{N}$ concentrations and stocks were not significantly increased by the $\mathrm{P}$ treatment but were



Fig. 1 The effects of fertilization on the distribution of soil aggregate sizes. Error bars are the standard error of the mean $(n=3)$. Means with different lowercase letters within same aggregate size fractions and soil depths are significantly different $(P<0.05)$. CK, control; $\mathrm{P}$, phosphorus; NPM, nitrogen+phosphorus+manure. The symbols represent the same below.
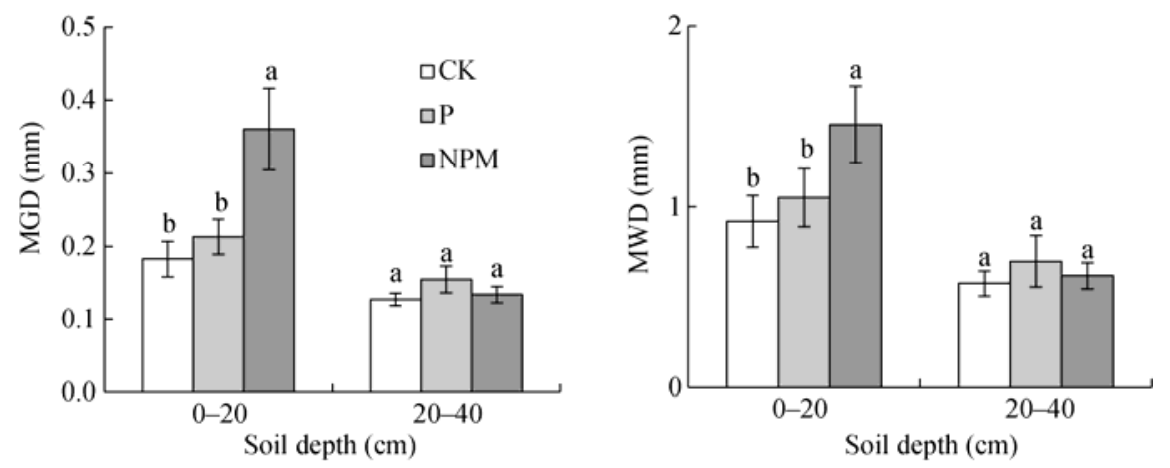

Fig. 2 The effects of fertilization on the mean geological diameter (MGD) and mean weight diameter (MWD) of soil aggregate sizes. Error bars represent the standard error of the mean $(n=3)$. Means with different lowercase letters within the same soil layer are significantly different $(P<0.05)$. 
significantly increased by NPM treatment in the $0-20$ cm layer (39\% and 25\%, respectively) (Fig. 3). On the other hand, the concentrations and stocks of $\mathrm{OC}$ and $\mathrm{N}$ in the deep soil layer $(20-40 \mathrm{~cm})$ were unaffected by
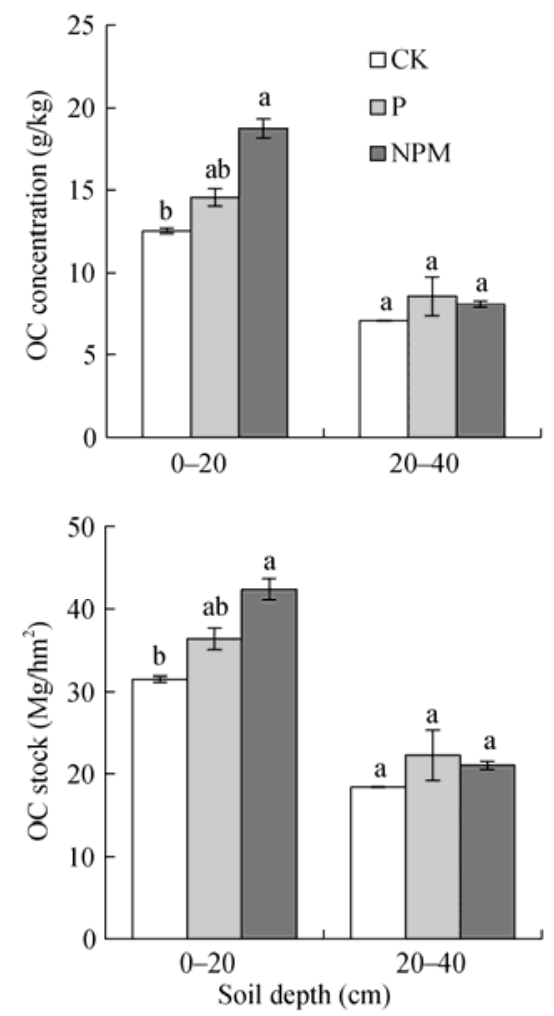

long-term fertilization, indicating that the effects of fertilization on total soil OC and $\mathrm{N}$ contents are limited to the top $20 \mathrm{~cm}$ soil depth in the semi-arid alfalfa grassland.
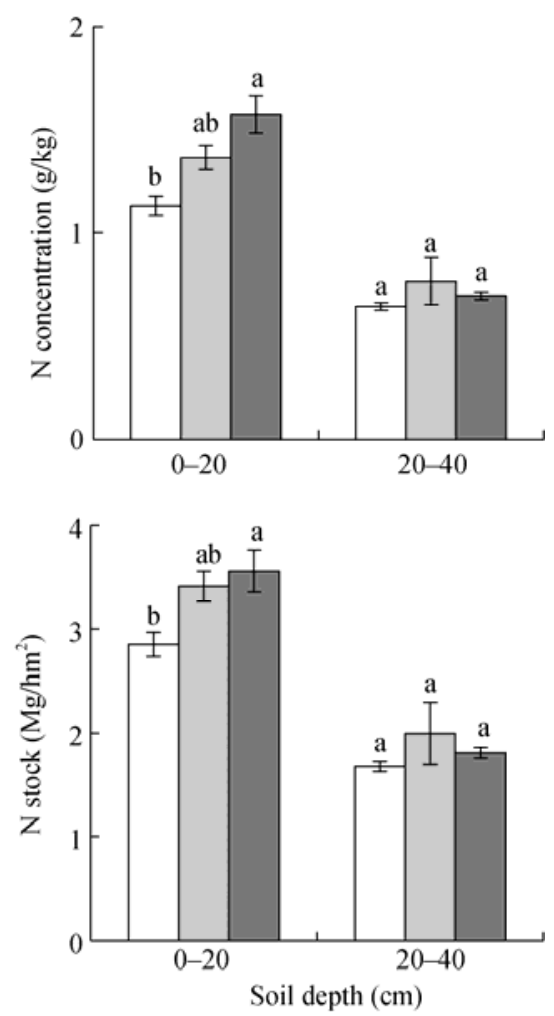

Fig. 3 The effects of fertilization on concentrations and stocks of organic carbon (OC) and nitrogen (N) in total soils. Error bars represent the standard error of the mean $(n=3)$. Means with different lowercase letters within the same soil layer are significantly different $(P<0.05)$.

\subsection{The effects of long-term fertilization on OC and $\mathrm{N}$ in aggregate size fractions}

The largest increase of soil $\mathrm{OC}$ and $\mathrm{N}$ concentration in the $0-20 \mathrm{~cm}$ layer occurred with the NPM treatment, whereas the largest increase in the $20-40 \mathrm{~cm}$ layer occurred with the P treatment (Fig. 4). For example, in the $0-20 \mathrm{~cm}$ layer, the $\mathrm{P}$ treatment increased OC concentrations by $4 \%, 11 \%, 11 \%$ and $3 \%$ in the $>2.0-\mathrm{mm}$, 2.0-0.25-mm, $0.25-0.053-\mathrm{mm}$ and $<0.053-\mathrm{mm}$ size fractions, respectively, and the NPM treatment increased OC concentrations by $18 \%, 27 \%, 74 \%$ and $18 \%$, respectively. Increases in $\mathrm{N}$ concentrations within aggregate size fractions from the $0-20 \mathrm{~cm}$ layer followed the same pattern. However, in the $20-40 \mathrm{~cm}$ layer, the increases in $\mathrm{OC}$ concentrations for each aggregate size fractions $(35 \%, 26 \%, 29 \%$ and $8 \%$, re- spectively) were greater caused by the $\mathrm{P}$ treatment than that resulted from the NPM treatment $(16 \%, 14 \%$, $25 \%$ and $6 \%$, respectively).

Long-term fertilization decreased the stocks of OC and $\mathrm{N}$ associated with the $<0.053-\mathrm{mm}$ size fraction but increased those associated with the $>2-\mathrm{mm}$, $2-0.25-\mathrm{mm}$ and $0.25-0.053-\mathrm{mm}$ size fractions. These increases varied with fertilization types and soil depths (Fig. 5). As with the changes in $\mathrm{OC}$ and $\mathrm{N}$ concentrations, the largest changes in $\mathrm{OC}$ and $\mathrm{N}$ stocks associated with aggregate size fractions in the 0-20 cm layer occurred in the NPM treatment (Fig. 5). These results represent that $\mathrm{OC}$ and $\mathrm{N}$ were concentrated in the coarse size fractions and redistributed from the fine size fractions to coarse size fractions during the 27 years of fertilization. 



Fig. 4 The effects of fertilization on concentrations of organic carbon $(\mathrm{OC})$ and nitrogen $(\mathrm{N})$ in different soil aggregates. Error bars represent the standard error of the mean $(n=3)$. Means with different lowercase letters within the same aggregate size fraction and soil layer are significantly different $(P<0.05)$.

\section{Discussion}

\subsection{The effects of long-term fertilization on soil aggregate size fractions}

We observed a significant influence of long-term fertilization fractions on the distribution of soil aggregate size fractions with NPM fertilization in the $0-20 \mathrm{~cm}$ layer and with $\mathrm{P}$ fertilization in the $20-40 \mathrm{~cm}$ layer. The increase in coarse aggregates and the decrease in fine size aggregates in the $0-20 \mathrm{~cm}$ layer as a result of NPM treatment accelerated the integration of fine particles into the coarse elements (Yu et al., 2012). This observation is similar to the results reported by Manna et al. (2006). The P fertilizer was also expected to increase the proportion of coarse size fractions in rela- tion to fine size fractions (Rasool et al., 2008; Lugato et al., 2010); however, tillage of the surface soil each year breaks up the aggregates, thereby decreasing the coarse size fractions and increasing the fine size fractions (Wang et al., 2009). Tillage during the study period may have offset the effects of the $\mathrm{P}$ fertilizer on soil aggregation in the surface soil $(0-20 \mathrm{~cm})$. On the other hand, the long-term application of $\mathrm{P}$ fertilizer can significantly increase the $\mathrm{P}$ content in the subsurface soil (20-40 cm). For example, Wei et al. (2006) found that the application of $P$ fertilizers over 18 years increased the available $\mathrm{P}$ by $530 \%$ at a depth of $20-32$ $\mathrm{cm}$ at the same site of alfalfa grassland, which could increase the coarse size fractions and decrease the fine size fractions in this layer. For the soils in the $20-40 \mathrm{~cm}$ layer were unaffected by tillage, and significant 


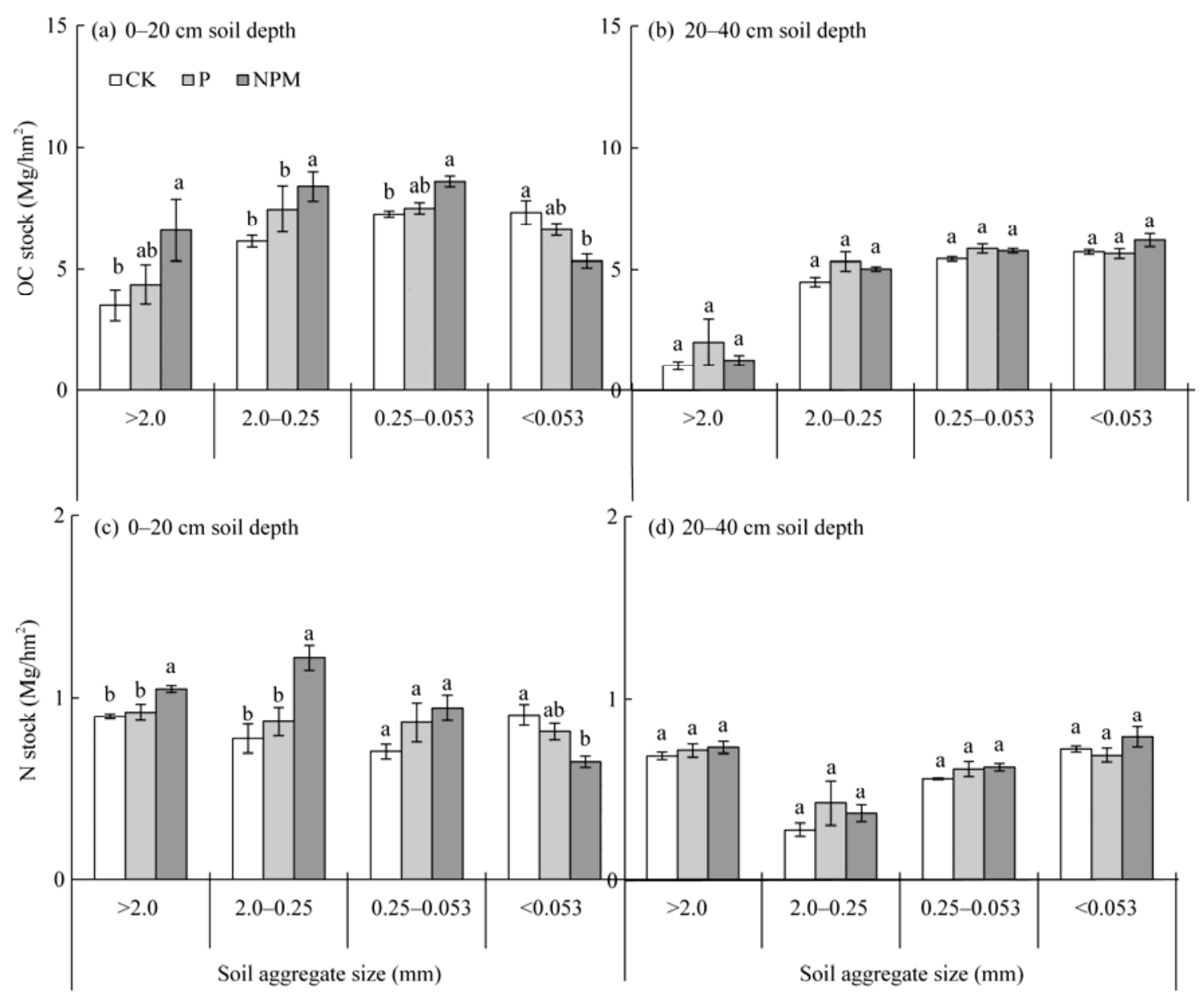

Fig. 5 The effects of fertilization on organic carbon (OC) and nitrogen (N) stocks in different soil aggregate size fractions. Error bars represent the standard error of the mean $(n=3)$. Means with different lowercase letters within the same aggregate size fraction and soil layer are significantly different $(P<0.05)$.

increased coarse size fractions and decreased fine size fractions were found in that layer after the $\mathrm{P}$ treatment. Our observations suggested that NPM treatment significantly improved the structure of surface soil and that $\mathrm{P}$ treatment improved the structure of subsurface soil at the study site.

The effects of fertilization on the distribution of soil aggregate sizes could also be influenced by the enhancement of plant root biomass, which could accelerate the formation of coarse aggregates (Schuman et al., 2002) and thus increase their mean weight diameter (Elliott, 1986).

\subsection{The effects of long-term fertilization on soil OC and $\mathrm{N}$}

Fertilization of 27 years resulted in the accumulation of $\mathrm{OC}$ and $\mathrm{N}$ in the soil aggregate size fractions, though this accumulation varied with fertilizer types and soil depths (Fig. 4). P and NPM treatments increased concentrations of $\mathrm{OC}$ and $\mathrm{N}$ in all aggregate size fractions.

Our results demonstrated that long-term fertilization led to large increases in $\mathrm{OC}$ concentrations and stocks within total soils at the $0-20 \mathrm{~cm}$ depth. Soil OC concentrations recorded in 2011 were approximately 2 to 3 times greater than those recorded in $1984 . \mathrm{N}$ concentrations in 2011 were approximately 1.4 to 2.0 times greater than those recorded in 1984. The increase in OC associated with the $\mathrm{P}$ treatment may be due to the increased input of plant material, additional above- and below-ground biomass and the transport of photosynthetically fixed atmospheric $\mathrm{C}$ into the soil (Bronick and Lal, 2005). The increase in OC associated with the NPM treatment, which includes the application of manure fertilizers, may be the result of 
similar processes. Manure fertilizers increase the proportion of coarse aggregates in topsoil, which could have physically prevented the loss of original OC from the soil (Celik et al., 2004).

In our study, $\mathrm{P}$ treatments increased the concentration and total amount of $\mathrm{N}$ in the $0-20 \mathrm{~cm}$ layer by $21 \%$ and $20 \%(P>0.05)$, respectively, whereas NPM treatments increased the concentration and total amount of $\mathrm{N}$ by $39 \%$ and $25 \%(P<0.05)$, respectively. However, the annual application of NPM added a total input of $7.2 \mathrm{Mg} \mathrm{N} / \mathrm{hm}^{2}$ into the soil over 27 years. This means that the increase in N in the NPM plot may be attributed to the input of $\mathrm{N}$ from the fertilizer rather than from the increased $\mathrm{N}$ fixation by alfalfa.

Our results demonstrated that NPM application increased the concentrations of $\mathrm{OC}$ and $\mathrm{N}$ in aggregate size fractions in the top $20 \mathrm{~cm}$ layer, whereas $\mathrm{P}$ treatment increased the concentrations of $\mathrm{OC}$ and $\mathrm{N}$ in aggregate size fractions in the $20-40 \mathrm{~cm}$ layer (Fig. 4). Our results further showed that the increases in OC and $\mathrm{N}$ concentrations in the coarse size fractions were larger than those in the fine size fractions. These results were consistent with our observation that NPM treatment increased the presence of coarse size fractions and decreased the fine size fractions in the 0-20 $\mathrm{cm}$ layer, whereas $\mathrm{P}$ treatment had the same effects throughout the $20-40 \mathrm{~cm}$ layer. This pattern may be attributed to the often greater organic matter content (and thus $\mathrm{C}$ and $\mathrm{N}$ ) in coarse size fractions compared with fine size fractions (Cambardella and Elliott, 1994).

The accumulation of $\mathrm{OC}$ and $\mathrm{N}$ in coarse size fractions has been well documented in different soil management systems (Cambardella and Elliott, 1994; Monreal et al., 1995; Six et al., 1998). While the redistribution of $\mathrm{OC}$ and $\mathrm{N}$ between different aggregate size fractions due to long-term fertilization was not well understood, the integration of fine particles into micro- and macro-aggregates during long-term fertilization led researchers to anticipate this process (Tisdall and Oades, 1982). The increase of macro-aggregates as a result of fertilization (Rasool et al., 2008; Yu et al., 2012) stems from the integration of relatively stable micro-aggregates and the silt+clay particles by plant roots, organic materials and organic binding agents (Onweremadu et al., 2007). Coarse aggregates can physically protect original and recently added $\mathrm{OC}$ and $\mathrm{N}$ from microbial attack and mineralization (Blanco and Lal, 2004), thereby favoring the accumulation of $\mathrm{OC}$ and $\mathrm{N}$ in the coarser size fractions. Long-term fertilization thus transfers $\mathrm{OC}$ and $\mathrm{N}$ from fine size fractions into coarse size fractions and physically protects them. We concluded that the effects of long-term fertilization on soil $\mathrm{OC}$ and $\mathrm{N}$ was due to the accumulation of $\mathrm{OC}$ and $\mathrm{N}$ in the coarse size fractions and the redistribution of $\mathrm{OC}$ and $\mathrm{N}$ from fine size fractions to coarse size fractions.

\section{Conclusions}

Coarse size fractions are generally highly susceptible to the loss of $\mathrm{OC}$ and $\mathrm{N}$ from any disturbance when compared with fine size fractions, which are relatively recalcitrant and stable. Additionally, $\mathrm{OC}$ and $\mathrm{N}$ in deep soils are relatively more stable than those in surface soils. Our results demonstrated NPM treatments lead to the accumulation of $\mathrm{OC}$ and $\mathrm{N}$ in coarse size fractions and the redistribution of $\mathrm{OC}$ and $\mathrm{N}$ from fine size fractions to coarse size fractions in the $0-20 \mathrm{~cm}$ soil layer. Total $35.8 \mathrm{Mg} / \mathrm{hm}^{2} \mathrm{OC}$ and $7.23 \mathrm{Mg} / \mathrm{hm}^{2} \mathrm{~N}$ were added to soils in our experiment through the application of NPM fertilizer annually for 27 years. However, our results showed that the NPM treatments increased soil $\mathrm{OC}$ and $\mathrm{N}$ by 13.57 and $0.85 \mathrm{Mg} / \mathrm{hm}^{2}$, respectively, in both soil layers, suggesting that most of the OC and $\mathrm{N}$ from the fertilizers were lost. Compared with NPM treatments, P treatments would increase $\mathrm{OC}$ and $\mathrm{N}$ in coarse size fractions from the subsurface layer $(20-40 \mathrm{~cm})$, where $\mathrm{OC}$ and $\mathrm{N}$ are relatively more stable than in surface soils. NPM and $\mathrm{P}$ treatments increased the biomass of alfalfa at the study site. For example, in this experiment, the above-ground biomass of alfalfa over 24 years increased $9 \%$ on plots that received the $\mathrm{P}$ treatment and $27 \%$ on those that received the NPM treatment when compared with the control. Phosphorous fertilization is therefore recommended in the study region.

\section{Acknowledgments}

This study was funded by the Program for New Century Excellent Talents in University (NCET-13-0487), the Program from 
Northwest A\&F University (2014YQ007), the National Basic Research Program of China (2009CB118604), the National Science and Technology Support for Major Projects of China (2011BAD31B01), the Knowledge Innovation Program of the Chinese Academy of Sciences (KZCX2-YW-JC408), Science and Technology Generalized Program for the Overall Development of Agriculture in Ningxia (NTKJ-2014-01), and the Scientific Research Program from Education Department of Shaanxi Province (11JK0650).

\section{References}

Aoyama M, Angers D A, N’Dayegamiye A. 1999. Particulate and mineral-associated organic matter in water-stable aggregates as affected by mineral fertilizer and manure applications. Canadian Journal of Soil Science, 79(2): 295-302.

Badaruddin M, Meyer D W. 1989. Forage legume effects on soil nitrogen and grain yield, and nitrogen nutrition of wheat. Agronomy Journal, 81(3): 419-424.

Beare M H, Hendrix P F, Cabrera M L, et al. 1994. Aggregate-protected and unprotected organic matter pools in conventional and no-tillage soils. Soil Science Society of America Journal, 58(3): 787-795.

Blanco-Canqui H, Lal R. 2004. Mechanisms of carbon sequestration in soil aggregates. Critical Reviews in Plant Sciences, 23(6): 481-504.

Bronick C J, Lal R. 2005. Soil structure and management: a review. Geoderma, 124(1-2): 3-22.

Cambardella C A, Elliott E T. 1994. Carbon and nitrogen dynamics of soil organic matter fractions from cultivated grassland soils. Soil Science Society of America Journal, 58(1): 123-130.

Cammeraat L H, Imeson A C. 1998. Deriving indicators of soil degradation from soil aggregation studies in southeastern Spain and southern France. Geomorphology, 23(2-4): 307-321.

Celik I, Ortas I, Kilic S. 2004. Effects of compost, mycorrhiza, manure and fertilizer on some physical properties of a Chromoxerert soil. Soil and Tillage Research, 78(1): 59-67.

Elliott E T. 1986. Aggregate structure and carbon, nitrogen, and phosphorus in native and cultivated soils. Soil Science Society of America Journal, 50(3): 627-633.

Fan J, Hao M D, Malhi S S, et al. 2011. Influence of 24 annual applications of fertilizers and/or manure to alfalfa on forage yield and some soil properties under dryland conditions in northern China. Crop and Pasture Science, 62(5): 437-443.

Food and Agriculture Organization of the United Nation (FAO). 1998. "World Reference Base for Soil Resources", World Soil Resources Report Number 84. FAO, Rome, Italy.

Gregorich E G, Carter M R, Doran J W, et al. 1997. Soil quality for crop production and ecosystem health. Developments in Soil Science, 25: 81-113.

He N P, Yu Q, Wu L, et al. 2008. Carbon and nitrogen store and storage potential as affected by land-use in a Leymus chinensis grassland of northern China. Soil Biology and Biochemistry, 40(12): 2952-2959.

Lal R, Kimble J, Follett R. 1997. Soil quality management for carbon sequestration. Nutrient Cycling in Agroecosystems, 10: 243-253.

Lugato E, Simonetti G, Morari F, et al. 2010. Distribution of organic and humic carbon in wet-sieved aggregates of different soils underlong-term fertilization experiment. Geoderma, 157(3-4): 80-85.

Madari B, Machado P, Torres E, et al. 2005. No tillage and crop rotation effects on soil aggregation and organic carbon in a Rhodic Ferralsol from southern Brazil. Soil and Tillage Research, 80(1-2): 185-200.

Manna M C, Swarup A, Wanjari R H, et al. 2006. Soil organic matter in a West Bengal Inceptisol after 30 years of multiple cropping and fertilization. Soil Science Society of America Journal, 70(1): 121-129.

Monreal C M, Schnitzer M, Schulten H R, et al. 1995. Soil organic structure in macro- and microaggregates of a cultivated Brown Chernozem. Soil Biology and Biochemistry, 27(6): 845-853.

Onweremadu E U, Onyia V N, Anikwe M A N. 2007. Carbon and nitrogen distribution in water-stable aggregates under two tillage techniques in Fluvisols of Owerri aera, southeastern Nigeria. Soil and Tillage Research, 97(2): 195-206.

Pinheiro E F M, Pereira M G, Anjos L H C. 2004. Aggregate distribution and soil organic matter under different till age systems for vegetable crops in Red Latosol from Brazil. Soil and Tillage Research, 77(1): 79-84.

Rasool R, Kukal S S, Hira G S. 2008. Soil organic carbon and physical properties as affected by long-term application of FYM and inorganic fertilizers in maize-wheat system. Soil and Tillage Research, 101(1-2): 31-36.

Reeder J D, Schuman G E, Bowman R A. 1998. Soil C and N changes on conservation reserve program lands in the Central Great Plains. Soil and Tillage Research, 47(3-4): 339-349.

Schuman G E, Janzen H H, Herrick J E. 2002. Soil carbon dynamics and potential carbon sequestration by rangelands. Environmental Pollution, 116(3): 391-396.

Shrestha G, Stahi P D. 2008. Carbon accumulation and storage in semiarid sagebrush steppe: Effects of long-term grazing exclusion. Agriculture Ecosystems and Environment, 125(1/4): 173-181.

Six J, Elliot E T, Paustian K, et al. 1998. Aggregation and soil organic matter accumulation in cultivated and native grassland soils. Soil Science Society of America Journal, 62(5): 1367-1377.

Six J, Elliott E T, Paustian K. 2000. Soil macroaggregate turnover and microaggregate formation: a mechanism for $\mathrm{C}$ sequestration under no-tillage agriculture. Soil Biology and Biochemistry, 32(14): 2099-2103.

Tisdall J M, Oades J M. 1982. Organic matter and water stable aggregate in soils. European Journal of Soil Science, 33(2): 141-163.

Wang Q, Zhang L, Li L, et al. 2009. Changes in carbon and nitrogen of Chernozem soil along a cultivation chronosequence in a semi-arid grassland. European Journal of Soil Science, 60: 916-923.

Wei X R, Hao M D, Shao M A, et al. 2006. Changes in soil properties and the availability of soil micronutrients after 18 years of cropping and fertilization. Soil and Tillage Research, 91: 120-130.

Whalen J K, Chang C. 2002. Macroaggregate characteristics in cultivated soils after 25 annual manure applications. Soil Science Society of America Journal, 66(5): 1637-1647.

Whalen J K, Hu Q C, Liu A. 2003. Compost applications increase water-stable aggregates in conventional and no-tillage systems. Soil Science Society of America Journal, 67(6): 1842-1847.

Yu H Y, Ding W X, Luo J F, et al. 2012. Effects of long-term compost and fertilizer application on stability of aggregate-associated organic carbon in an intensively cultivated sandy loam soil. Biology and Fertility of Soils, 48(3): 325-336. 